Article

\title{
Piperidinium and Pyrrolidinium Ionic Liquids as Precursors in the Synthesis of New Platinum Catalysts for Hydrosilylation
}

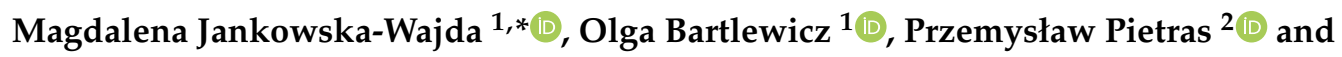 \\ Hieronim Maciejewski 1,2 (D) \\ 1 Faculty of Chemistry, Adam Mickiewicz University, Uniwersytetu Poznańskiego 8, 61-614 Poznań, Poland; \\ olga.bartlewicz@amu.edu.pl (O.B.); hieronim.maciejewski@amu.edu.pl (H.M.) \\ 2 Adam Mickiewicz University Foundation, Poznań Science and Technology Park, Rubież 46, 61-612 Poznań, \\ Poland; przemyslaw.pietras@ppnt.poznan.pl \\ * Correspondence: magdajw@amu.edu.pl
}

Received: 11 July 2020; Accepted: 7 August 2020; Published: 10 August 2020

\begin{abstract}
Six new air-stable anionic platinum complexes were synthesized in simple reactions of piperidinium [BMPip] $\mathrm{Cl}$ or pyrrolidinium [BMPyrr] $\mathrm{Cl}$ ionic liquids with platinum compounds $\left(\left[\mathrm{Pt}(\mathrm{cod}) \mathrm{Cl}_{2}\right]\right.$ or $\left.\mathrm{K}_{2}\left[\mathrm{PtCl}_{6}\right]\right)$. All these compounds were subjected to isolation and spectrometric characterization using NMR and ESI-MS techniques. Furthermore, the determination of melting points and thermal stability of the above derivatives was performed with the use of thermogravimetric analysis. The catalytic performance of the synthesized complexes was tested in hydrosilylation of 1-octene and allyl glycidyl ether with 1,1,1,3,5,5,5-heptamethyltrisiloxane. The study has shown that they have high catalytic activity and are insoluble in the reaction medium which enabled them to isolate and reuse them in consecutive catalytic cycles. The most active complex [ $\mathrm{BMPip}_{2}\left[\mathrm{PtCl}_{6}\right]$ makes it possible to conduct at least 10 catalytic runs without losing activity which makes it an attractive alternative not only to commonly used homogeneous catalysts, but also to heterogeneous catalysts for hydrosilylation processes. The activity of the studied catalysts is also affected by the kind of anion and, to some extent, the kind of cation.
\end{abstract}

Keywords: ionic liquids; biphasic catalysis; platinum complexes; hydrosilylation

\section{Introduction}

Environmental, economic and technological reasons prompt researchers to pay more and more attention to planning new paths of synthesis of chemical compounds and continuing work on already known reactions and processes successfully employed in the industry, which can be optimized in the aspects of the improvement in yield, reduction in produced waste and possibility of reusing catalysts. Attempts are made at reaching the equilibrium between the costs of conducting a process, its yield, and the environmental impact. All these aspects are in line with the premises of "green chemistry" [1]. One of the processes commonly used on the industrial scale and being the main way of synthesis of organosilicon compounds is hydrosilylation [2-4]. Catalysts for this process are most often transition-metal-based systems of which the most important are platinum complexes, particularly Karstedt $\left(\left[\mathrm{Pt}_{2}\left\{\mathrm{H}_{2} \mathrm{C}=\mathrm{CHSiMe}\right)_{2} \mathrm{O}\right\}_{3}\right]$ and Speier $\left(\mathrm{H}_{2} \mathrm{PtCl}_{6} / \mathrm{i}-\mathrm{PrOH}\right)$ catalysts [5]. Taking into consideration high price of platinum and the necessity to separate the catalyst from the postreaction mixture (because the presence of heavy metals, even in trace amounts, is impermissible in many applications of the reaction product), efforts are made to employ catalytic systems based on other metals or to heterogenize the most active platinum complexes $[5,6]$. 
In recent years, a significant role in the catalytic processes has been played by ionic liquids which can serve as solvents, immobilizing agents for metal complexes, cocatalysts, and catalysts [7-12]. The ionic liquids have been employed in many reactions, one of which is hydrosilylation. In most cases of the latter reaction, ionic liquids dissolved and immobilized metal complexes (mainly those of platinum and rhodium), and formed biphasic systems with the reagents. This role of ionic liquids enabled easy isolation of a catalyst dissolved in them and its reuse. The most often applied ionic liquids were imidazolium [13-17], phosphonium [18,19], ammonium [20], pyrylium [21], and morpholinium [22] ones.

The ionic liquid can also be the element of a complex compound structure which is exemplified by the employment of ionic liquids as substituents in ligands (most often phosphine ones) which at a further stage serve for metal complexation [23-25]. Platinum complexes of this type were applied in reactions of hydrosilylation of alkenes [26] and alkynes [27]. Ionic liquids that contain metal atoms in their structure are another possibility of this kind of application. This group of derivatives is exemplified by halometallate ionic liquids which can be prepared easily by reacting metal halide with organic halide [28-33]. The first and prevalent derivatives have been chloroaluminate ionic liquids [34], albeit currently ionic liquids containing $\mathrm{Co}, \mathrm{Ir}, \mathrm{Au}, \mathrm{Ni}, \mathrm{Pd}$, and $\mathrm{Pt}$ are also known [28-33]. The platinates known hitherto were solely imidazole derivatives: $[\mathrm{EMIM}]_{2}\left[\mathrm{PtCl}_{4}\right],[\mathrm{EMIM}]_{2}\left[\mathrm{PtCl}_{6}\right]$, and $[\mathrm{BMIM}]_{2}\left[\mathrm{PtCl}_{4}\right],[\mathrm{BMIM}]_{2}\left[\mathrm{PtCl}_{6}\right][35,36]$. Recently, our research group obtained next platinates with imidazole and pyridine derivatives and applied them as hydrosilylation catalysts [37,38]. It was the first report on the employment of platinum anionic complexes of this type in the hydrosilylation process. All the complexes have shown high catalytic activity and insolubility in the reagents which enabled them to separate and recycle them.

The simple method of synthesis, high stability, and high activity of the catalysts, as well as the possibility to recycle the latter, which translates into economic and ecological effects, have inspired us to continue studies of this subject and obtain new derivatives. This work was aimed at obtaining new platinates by reactions of platinum salts and platinum chloride complexes with pyrrolidine and piperidine derivatives, their isolation and spectroscopic characterization, as well as the determination of their catalytic activity for hydrosilylation. For the synthesis of the platinates, we have chosen pyrrolidine and piperidine derivatives to compare their properties with those of imidazole and pyridine derivatives obtained earlier [37].

\section{Results and Discussion}

To synthesize platinum-containing complexes, two platinum precursors, $\left[\mathrm{Pt}(\operatorname{cod}) \mathrm{Cl}_{2}\right]$ and $\mathrm{K}_{2}\left[\mathrm{PtCl}_{6}\right]$, as well as derivatives of piperidine (1-butyl-1-methyl piperidinium chloride, [BMPip]Cl) and pyrrolidine (1-butyl-1-methylpyrrolidinium chloride, [BMPyrr]Cl) have been used. In the starting precursors, platinum was present at different oxidation states which made it possible to obtain tetrachloroplatinates and hexachloroplatinates. In the case of the synthesis of tetrachloroplatinates, depending on the amount of the precursor and ionic liquid, complexes were formed with a different form of the anion. When equimolar amounts of the precursor and ionic liquid were used, the complex with anion in the form of the dimer was obtained, whereas in the case of using two-fold excess of ionic liquid the complex with anion in the monomeric form was created. The syntheses of six new platinum complexes were conducted according to Scheme 1. 


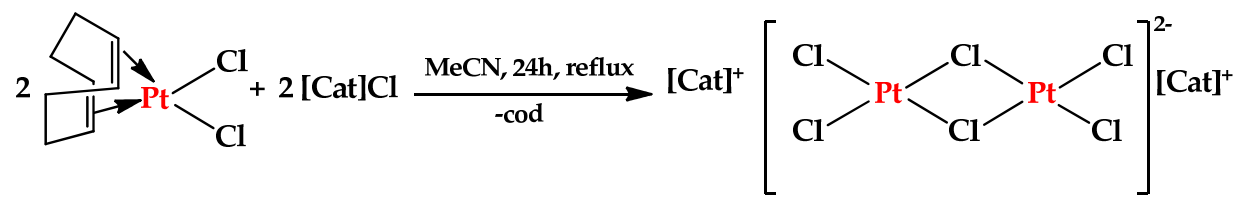

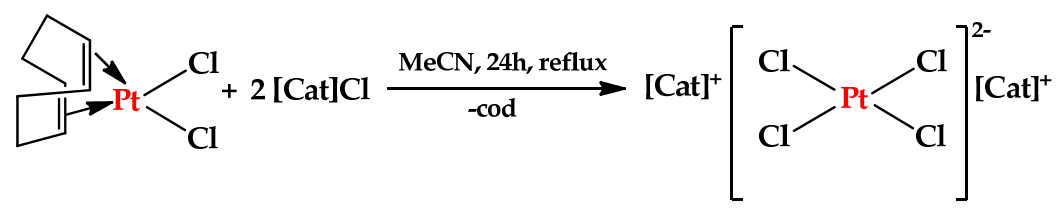

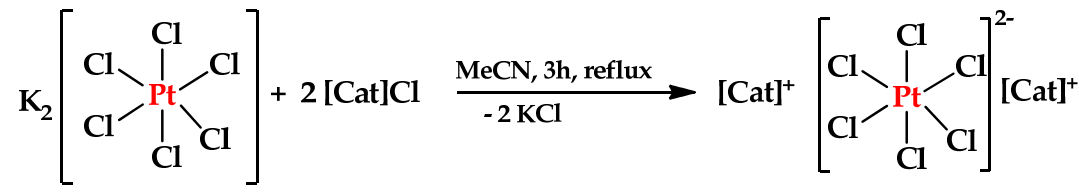<smiles>CCCCC1(C)CCCC[N+]1(C)CC</smiles>

Scheme 1. The methods of the synthesis of tetrachloroplatinate, hexachlorodiplatinate, and hexachloroplatinate complexes applied in the study.

The synthesis of the above complexes is very simple and consists of the dissolution of platinum precursor and ionic liquid in acetonitrile followed by stirring under reflux for several hours. In the case of the reaction with $\left[\mathrm{Pt}(\operatorname{cod}) \mathrm{Cl}_{2}\right]$, after cooling down, the solvent was evaporated together with cyclooctadiene, whereas in the case of the reaction with $\mathrm{K}_{2}\left[\mathrm{PtCl}_{6}\right]$, the filtration of the precipitated $\mathrm{KCl}$ preceded the solvent evaporation. All the complexes were obtained with very high yields ranging from 89 to $96 \%$. These compounds are stable in air and no special storage conditions are required.

The obtained complexes were subjected to characterization by ${ }^{1} \mathrm{H}$ and ${ }^{13} \mathrm{C}$ NMR spectroscopy and ESI-MS mass spectrometry. The spectra of the complexes were compared with the spectra of starting reagents. Noteworthy differences were found in the values of chemical shifts of the signals originated from methyl group and $\mathrm{CH}_{2}$ groups bound directly to the nitrogen present in piperidinium and pyrrolidinium cations in the starting ionic liquids compared to tetrachloroplatinate, hexachlorodiplatinate, and hexachloroplatinate complexes with the same cations. The differences in chemical shifts observed for tetrachloroplatinate and hexachloroplatinate complexes range from 0.4 to $0.6 \mathrm{ppm}$, whereas for hexachlorodiplatinate ones from 0.4 to $0.8 \mathrm{ppm}$ and depend on the kind of cation. The presence of a hydrogen bond had no significant effect on chemical shift values in the ${ }^{13} \mathrm{C}$ NMR spectra.

In the ESI-MS spectra, MS(+) signals from cation and MS(-) ones from chloroplatinate anion were observed. In the MS(+) spectra of all complexes, very intense signals corresponding to molecular peaks of cations: $\mathrm{m} / \mathrm{z} 156.17$ [BMPip] $^{+}$and 142.13 [BMPyrr] $^{+}$were present. The MS(-) spectra of tetrachloroplatinate compounds contain multiplets resulting from the presence of three platinum isotopes. The most intense signal was at $\mathrm{m} / \mathrm{z} 335.84$ originating from $\left[\mathrm{PtCl}_{4}\right]^{2-}$. Signals indicating the presence of $\left[\mathrm{PtCl}_{2}\right]^{2-}, \mathrm{m} / \mathrm{z} 265.15$ and $\mathrm{m} / \mathrm{z} 300.89$, corresponding to $\left[\mathrm{PtCl}_{3}\right]^{-} /\left[\mathrm{Pt}_{2} \mathrm{Cl}_{6}\right]^{2-}$, were also observed. On the other hand, in the case of hexachloroplatinate compounds, signals originating from cations: 156.17 [BMPip] $^{+}$and 142.13 [BMPyrr] $^{+}$were seen. In the MS(-) spectra, characteristic multiplets were visible which originated from platinum isotopes: the most intense of them at $\mathrm{m} / \mathrm{z}$ 265.15 corresponded to $\left[\mathrm{PtCl}_{2}\right]^{2-}$, another one at $\mathrm{m} / \mathrm{z} 300.98$ was ascribed to $\left[\mathrm{PtCl}_{3}\right]^{-} /\left[\mathrm{Pt}_{2} \mathrm{Cl}_{6}\right]^{2-}$, and the signal at $\mathrm{m} / \mathrm{z}$ 603.47, which is characteristic of the dimeric complex, originated from $\left[\mathrm{Pt}_{2} \mathrm{Cl}_{6}\right]^{2-}$.

For all obtained complexes, melting points were measured and the results are shown in Table 1. 
Table 1. Melting points of the synthesized chloroplatinate complexes.

\begin{tabular}{cc}
\hline Catalyst & Melting Point $\left[{ }^{\circ} \mathbf{C}\right]$ \\
\hline$[\mathrm{BMPip}]_{2}\left[\mathrm{PtCl}_{4}\right]$ & 151 \\
{$[\mathrm{BMPyrr}]_{2}\left[\mathrm{PtCl}_{4}\right]$} & 134 \\
{$[\mathrm{BMPip}]_{2}\left[\mathrm{PtCl}_{6}\right]$} & 178 \\
{$[\mathrm{BMPyrr}]_{2}\left[\mathrm{PtCl}_{6}\right]$} & 169 \\
{$[\mathrm{BMPip}]_{2}\left[\mathrm{Pt}_{2} \mathrm{Cl}_{6}\right]$} & 189 \\
{$[\mathrm{BMPyrr}]_{2}\left[\mathrm{Pt}_{2} \mathrm{Cl}_{6}\right]$} & 165 \\
\hline
\end{tabular}

The obtained results permit us to conclude that from among complexes with the same cation, hexachloroplatinate complexes have higher melting points than tetrachloroplatinate ones.

Melting points of complexes with anion in the dimeric form are close to or higher than those of hexachloroplatinate complexes. According to the literature, complexes of higher anion symmetry have higher melting points [36] and hexachloroplatinates are characterized by a higher symmetry $\left(\mathrm{O}_{h}\right)$ compared to tetrachloroplatinates $\left(\mathrm{D}_{4 \mathrm{~h}}\right.$ symmetry). In the case when complexes with the same anion are compared, one can note that complexes with the [BMPip] cation have higher melting points than complexes with the [BMPyrr] cation.

The thermal stability of the studied compounds was determined by conducting thermogravimetric analysis (TGA) and the results are presented in Figure 1. The temperature at which $10 \%$ weight loss occurred was taken as the decomposition temperature (Table 2). The above weight loss value has been chosen to distinguish the decomposition temperature from water desorption temperature. The results listed in Table 2 made it possible to establish that hexachloroplatinate and hexachlorodiplatinate complexes are characterized by higher decomposition temperatures than tetrachloroplatinate complexes. From among the studied complexes, the highest decomposition temperature was found for hexachloroplatinate complex with pyrrolidinium cation, albeit all the temperatures were fairly close one to another and exceeded $200^{\circ} \mathrm{C}$ which permits to classify all the complexes as thermally stable. This is crucial from the viewpoint of their application in the catalytic processes conducted at elevated temperatures.

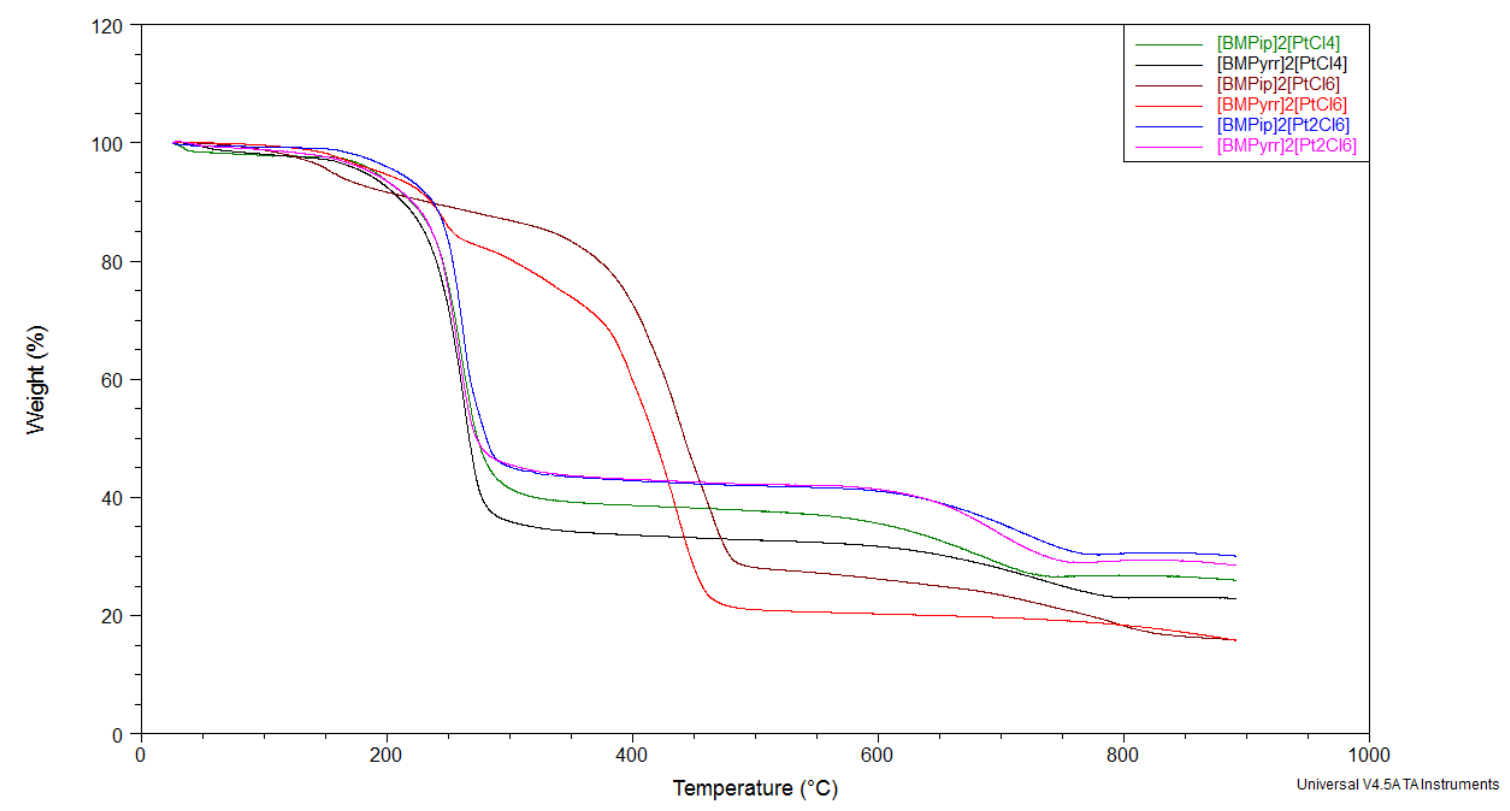

Figure 1. Thermogravimetric curves of chloroplatinate complexes. 
Table 2. Decomposition temperatures of the studied compounds at $10 \%$ of weight loss.

\begin{tabular}{cc}
\hline Catalyst & Decomposition Temperature $\left[{ }^{\circ} \mathrm{C}\right]$ \\
\hline$[\mathrm{BMPip}]_{2}\left[\mathrm{PtCl}_{4}\right]$ & 219.84 \\
{$[\mathrm{BMPyrr}]_{2}\left[\mathrm{PtCl}_{4}\right]$} & 212.95 \\
{$[\mathrm{BMPip}]_{2}\left[\mathrm{PtCl}_{6}\right]$} & 225.88 \\
{$[\mathrm{BMPyrr}]_{2}\left[\mathrm{PtCl}_{6}\right]$} & 233.07 \\
{$[\mathrm{BMPip}]_{2}\left[\mathrm{Pt}_{2} \mathrm{Cl}_{6}\right]$} & 220.69 \\
{$[\mathrm{BMPyrr}]_{2}\left[\mathrm{Pt}_{2} \mathrm{Cl}_{6}\right]$} & 237.40 \\
\hline
\end{tabular}

The essential stage of the study was the application of the prepared complexes as catalysts for hydrosilylation. The activity and selectivity of the developed catalysts were evaluated in the model reactions of hydrosilylation of 1-octene and allyl glycidyl ether with 1,1,1,3,5,5,5-heptamethyltrisiloxane (HMTS). Based on the results of our earlier studies, we conducted the catalytic measurements in analogous conditions, i.e., at $110^{\circ} \mathrm{C}$ for $1 \mathrm{~h}$ [37]. After the reaction completion, the composition of the postreaction mixture was analyzed using GC techniques. The analyses have shown the formation of $\beta$-addition products only (in compliance with Scheme 2). No presence of other products, e.g., $\alpha$-addition or the competitive reaction of olefin isomerization, was observed.

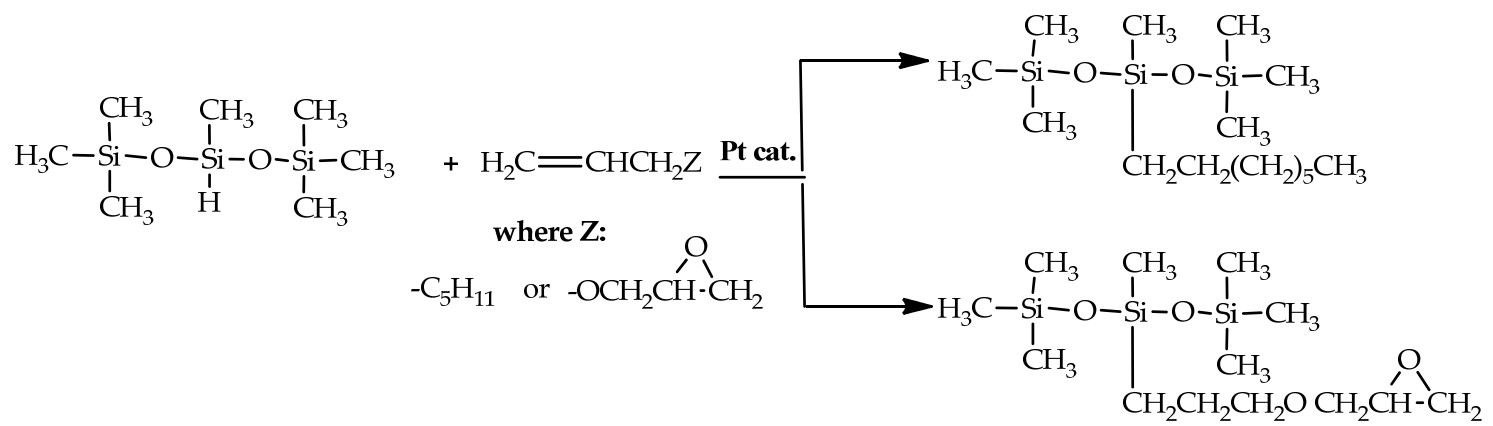

Scheme 2. The model reaction of hydrosilylation of 1-octene/allyl glycidyl ether with 1,1,1,3,5,5,5-heptamethyltrisiloxane.

The product yields in the reactions of hydrosilylation of 1-octene and allyl glycidyl ether, catalyzed by the studied platinum complexes are presented in Table 3 .

Table 3. The product yields in the reactions of hydrosilylation of 1-octene and allyl glycidyl ether with 1,1,1,3,5,5,5-heptamethyltrisiloxane, catalyzed by platinum complexes.

\begin{tabular}{ccc}
\hline \multirow{2}{*}{ Catalyst } & \multicolumn{2}{c}{ Product Yield in the Reaction with } \\
\cline { 2 - 3 } & 1-octene ${ }^{\mathbf{1}}[\%]$ & Allyl Glycidyl Ether ${ }^{\mathbf{2}}$ [\%] \\
\hline$[\mathrm{BMPip}]_{2}\left[\mathrm{PtCl}_{4}\right]$ & 94 & 96 \\
{$[\mathrm{BMPip}]_{2}\left[\mathrm{PtCl}_{6}\right]$} & 99 & 94 \\
{$\left[\mathrm{BMPip}_{2}\left[\mathrm{Pt}_{2} \mathrm{Cl}_{6}\right]\right.$} & 94 & 99 \\
{$\left[\mathrm{BMPyrr}_{2}\left[\mathrm{PtCl}_{4}\right]\right.$} & 93 & 85 \\
{$[\mathrm{BMPyrr}]_{2}\left[\mathrm{PtCl}_{6}\right]$} & 95 & 89 \\
{$[\mathrm{BMPyrr}]_{2}\left[\mathrm{Pt}_{2} \mathrm{Cl}_{6}\right]$} & 93 & 98 \\
\hline${ }^{1}[\mathrm{HSi} \equiv]:\left[-\mathrm{CH}=\mathrm{CH}_{2}\right]:[\mathrm{cat}]=1: 1: 10^{-4} ; \mathrm{T}=110^{\circ} \mathrm{C} ; \mathrm{t}=1 \mathrm{~h},{ }^{2}[\mathrm{HSi} \equiv]:\left[-\mathrm{CH}=\mathrm{CH}_{2}\right]:[\mathrm{cat}]=1: 1.2: 10^{-4} ; \mathrm{T}=110^{\circ} \mathrm{C} ; \mathrm{t}=1 \mathrm{~h}$.
\end{tabular}

Based on the obtained results one can say that all the complexes have shown high catalytic activity and enabled them to obtain a product with high yield. In the case of the reaction with 1-octene, yields obtained in the presence of respective complexes were very similar, whereas, in that of the reaction with allyl glycidyl ether catalyzed by complexes with piperidinium cation, the yield was a bit higher. However, also in the latter case, the differences were small. 
All employed complexes are insoluble in reagents which allows their isolation from postreaction mixtures and their reuse in subsequent reaction cycles after adding a new portion of reactants.

The yields obtained in 10 subsequent cycles of the reaction of 1-octene hydrosilylation, catalyzed by the same portion of catalyst, are shown in Figure 2 and Table 4.

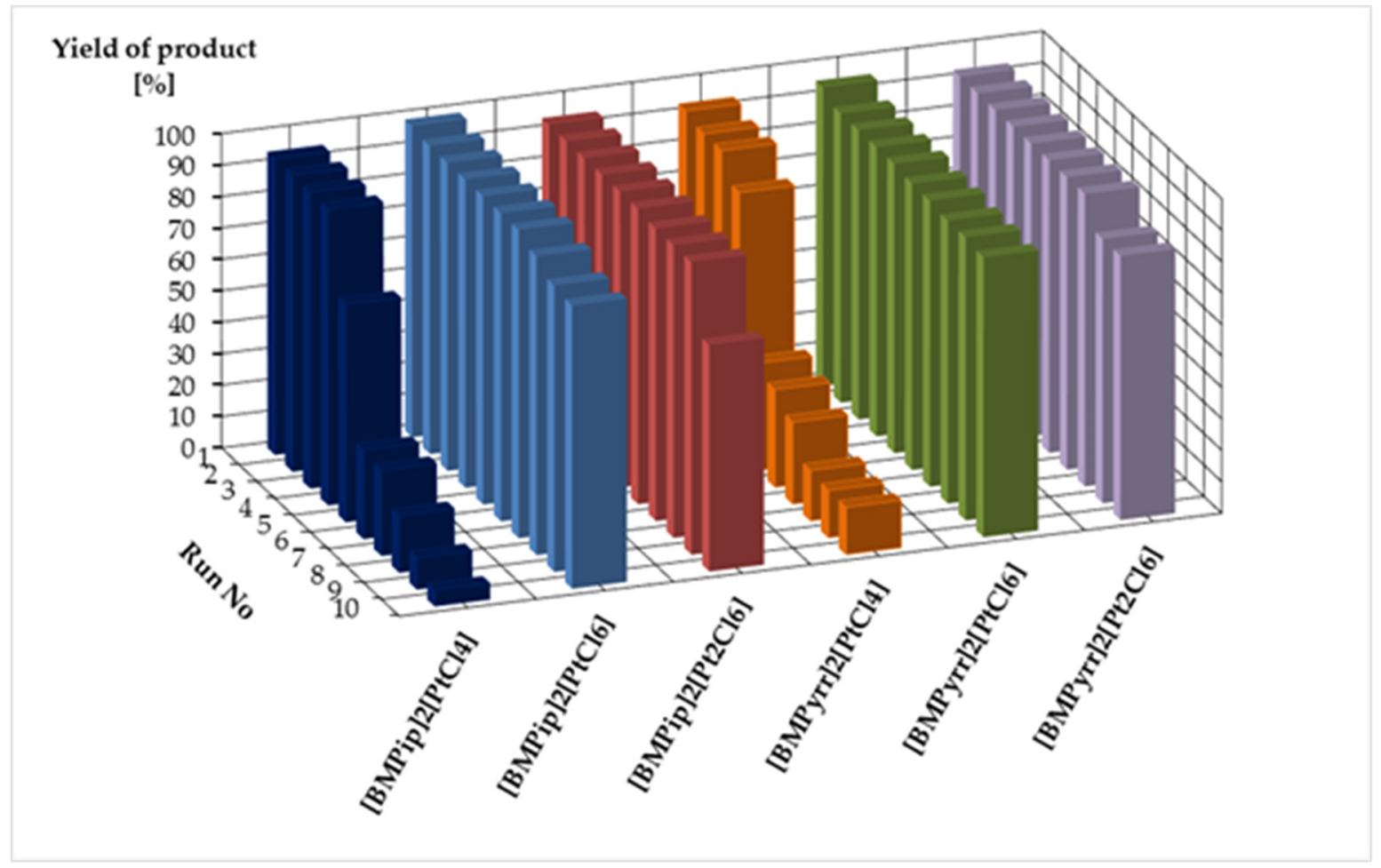

Figure 2. Yields of the product of hydrosilylation of 1-octene with 1,1,1,3,5,5,5-heptamethyltrisiloxane as determined for 10 subsequent reaction cycles catalyzed by the same catalyst portion.

Table 4. Product yields and TON values for hydrosilylation of 1-octene with heptamethyltrisiloxane (HMTS) catalyzed by anionic platinum complexes.

\begin{tabular}{ccc}
\hline Catalyst & Yield of Product in Subsequent Cycle [\%] & Total TON \\
\hline$[\mathrm{BMPip}]_{2}\left[\mathrm{PtCl}_{4}\right]$ & $94(94,94,94,69,28,27,18,10,5)$ & 53,300 \\
{$[\mathrm{BMPip}]_{2}\left[\mathrm{PtCl}_{6}\right]$} & $99(98,98,98,98,98,98,95,91,90)$ & 96,300 \\
{$[\mathrm{BMPip}]_{2}\left[\mathrm{Pt}_{2} \mathrm{Cl}_{6}\right]$} & $94(94,94,94,94,94,93,93,93,72)$ & 91,500 \\
{$[\mathrm{BMPyrr}]_{2}\left[\mathrm{PtCl}_{4}\right]$} & $93(91,91,83,34,31,26,16,15,15)$ & 49,500 \\
{$[\mathrm{BMPyrr}]_{2}\left[\mathrm{PtCl}_{6}\right]$} & $95(92,92,92,92,91,91,90,90,89)$ & 91,400 \\
{$[\mathrm{BMPyrr}]_{2}\left[\mathrm{Pt}_{2} \mathrm{Cl}_{6}\right]$} & $93(93,93,93,93,93,93,93,84,84)$ & 91,200 \\
\hline
\end{tabular}

$[\mathrm{HSi}=]:[\mathrm{CH}=\mathrm{CH}]:[\mathrm{cat}]=1: 1: 10^{-4} ; \mathrm{T}=110^{\circ} \mathrm{C} ; \mathrm{t}=1 \mathrm{~h}$.

The obtained results point to significant differences in the activity of the studied platinum-containing catalysts and to a significant influence of the kind of anion on the catalytic activity observed in subsequent reaction cycles. Figure 2 clearly shows that complexes with $\left[\mathrm{PtCl}_{6}\right]^{2-}$ and $\left[\mathrm{Pt}_{2} \mathrm{Cl}_{6}\right]^{2-}$ anions (particularly with the former one) show the highest stability and reproducibility. The mentioned complexes are permitted to obtain the product with very high yields in all 10 cycles. The catalytic activity can be easily compared by calculating TON values which are presented in Table 4 . It is worth mentioning that the TON values were calculated (for the sake of comparison) for 10 conducted reaction cycles only, although the activity of some complexes was still very high, hence they could be employed in further cycles. Based on the obtained results, one can say that in this case, the effect of the cation is small, albeit the complexes with piperidinium cation have slightly higher activity. From among all complexes studied, the complex $\left[\mathrm{BMPip}_{2}\left[\mathrm{PtCl}_{6}\right]\right.$ was the most active. To confirm 
the reaction course in subsequent cycles, we studied the reaction using an in situ FTIR probe that made it possible to follow the reaction course in real-time. In the above study, we tracked the decline in the band characteristic of the $\equiv \mathrm{SiH}$ group. Due to the selective formation of only one product, as shown by chromatograhic analysis of the postreaction mixture, the measured conversion well correlates with the values of product yield determined by chromatographic methods. The obtained $\equiv \mathrm{SiH}$ conversions in the hydrosilylation reaction catalyzed by the same portion of the $\left[\mathrm{BMPip}_{2}\left[\mathrm{PtCl}_{6}\right]\right.$ complex in subsequent cycles are presented in Figure 3.

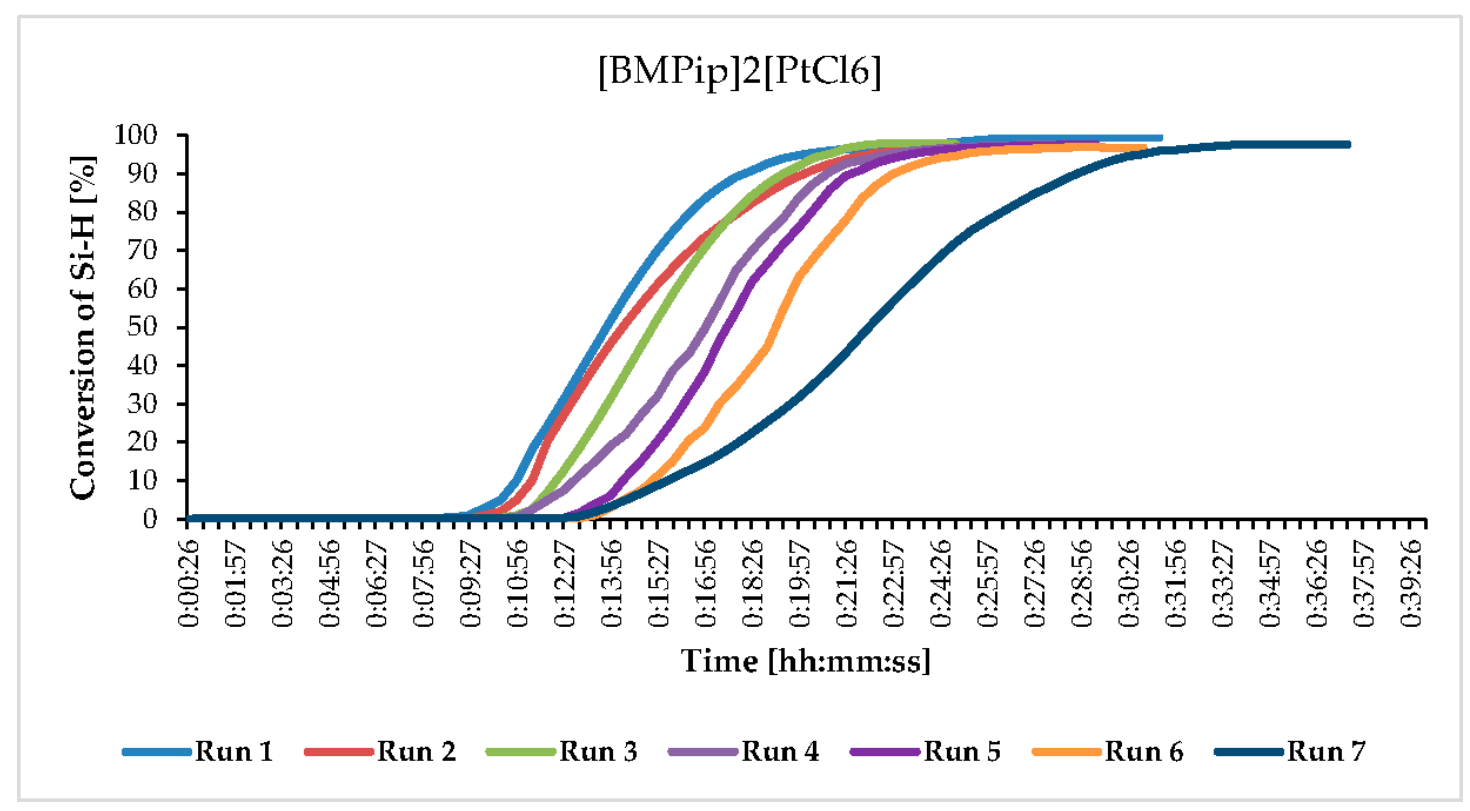

Figure 3. The change in the conversion of $\equiv \mathrm{SiH}$ as a function of time for the reaction catalyzed by $[\mathrm{BMPip}]_{2}\left[\mathrm{PtCl}_{6}\right]$.

The measurements were conducted for seven cycles and it was found that in each cycle (from the time of the reaction initiation to that at which the final conversion was reached), the reaction course was very fast and lasted from 8 to $10 \mathrm{~min}$. It was also noticed that the inductive period became longer in subsequent cycles, but the reaction profiles were similar and the conversions were on the same level. Analogous measurements were carried out for the reaction catalyzed by the complex $[\mathrm{BMPyrr}]_{2}\left[\mathrm{PtCl}_{4}\right]$ whose activity was the lowest. The obtained results are presented in Figure 4.

In this case, the catalytic activity decreased in subsequent cycles. Although in the first cycle the reaction proceeds very fast (about $10 \mathrm{~min}$ ), in the further cycles (until reaching the final conversion) the reaction time becomes longer and longer. Moreover, the activity considerably decreases after the fourth cycle (this was also noticed in the results of chromatographic analysis) and the conversion reaches the value of about $30 \%$.

The second reaction studied was hydrosilylation of allyl glycidyl ether in which the activity of all complexes in the first cycle was high (Table 3). This is why we isolated the catalysts and used them in subsequent catalytic cycles. The obtained results are presented in Figure 5 and Table 5 . In this case, the results were even more diversified and the highest stability and reproducibility were found for the complexes with a hexachloroplatinic anion. 


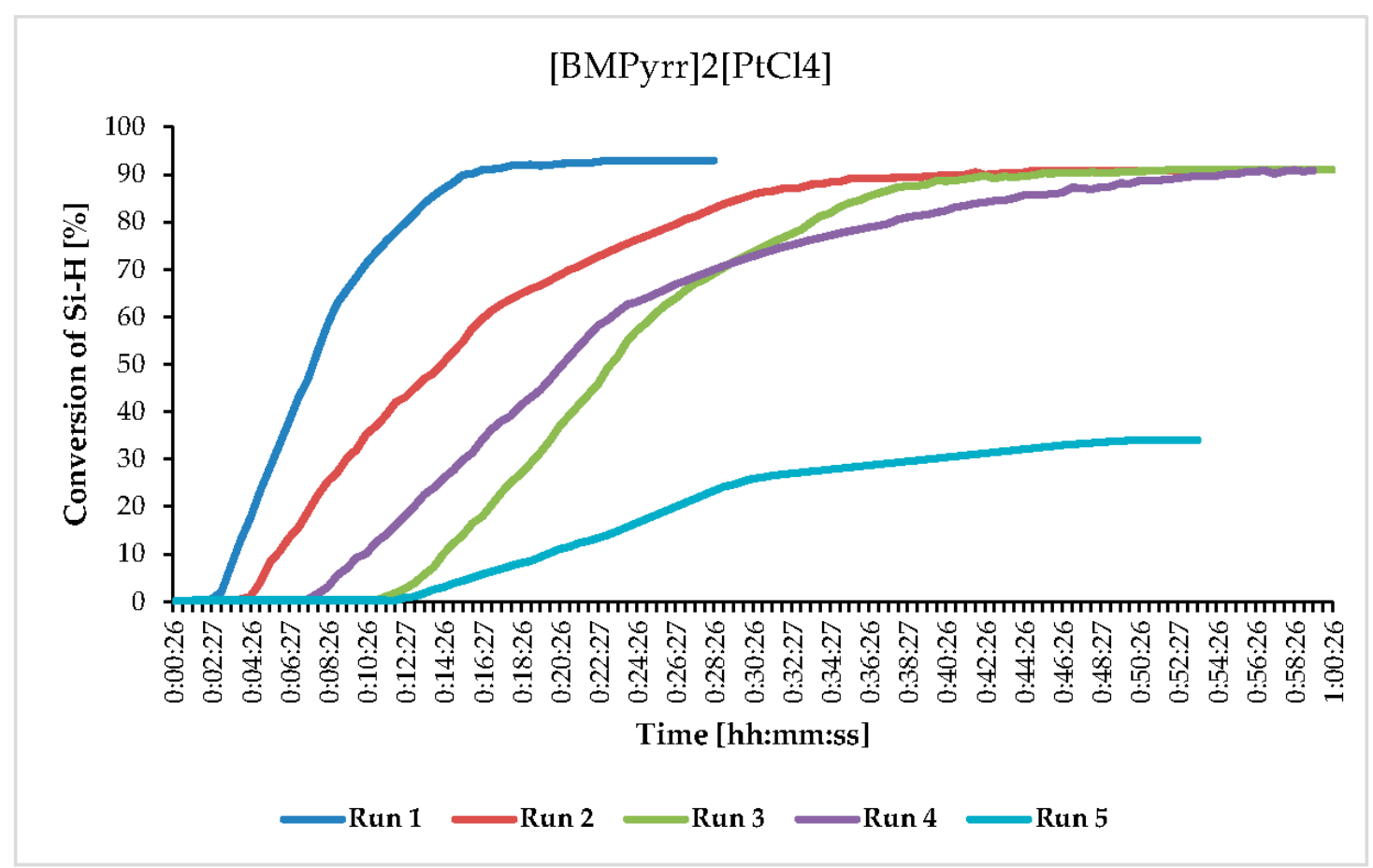

Figure 4. The change in the conversion of $\equiv \mathrm{SiH}$ as a function of time for the reaction catalyzed by $[\mathrm{BMPyrr}]_{2}\left[\mathrm{PtCl}_{4}\right]$.

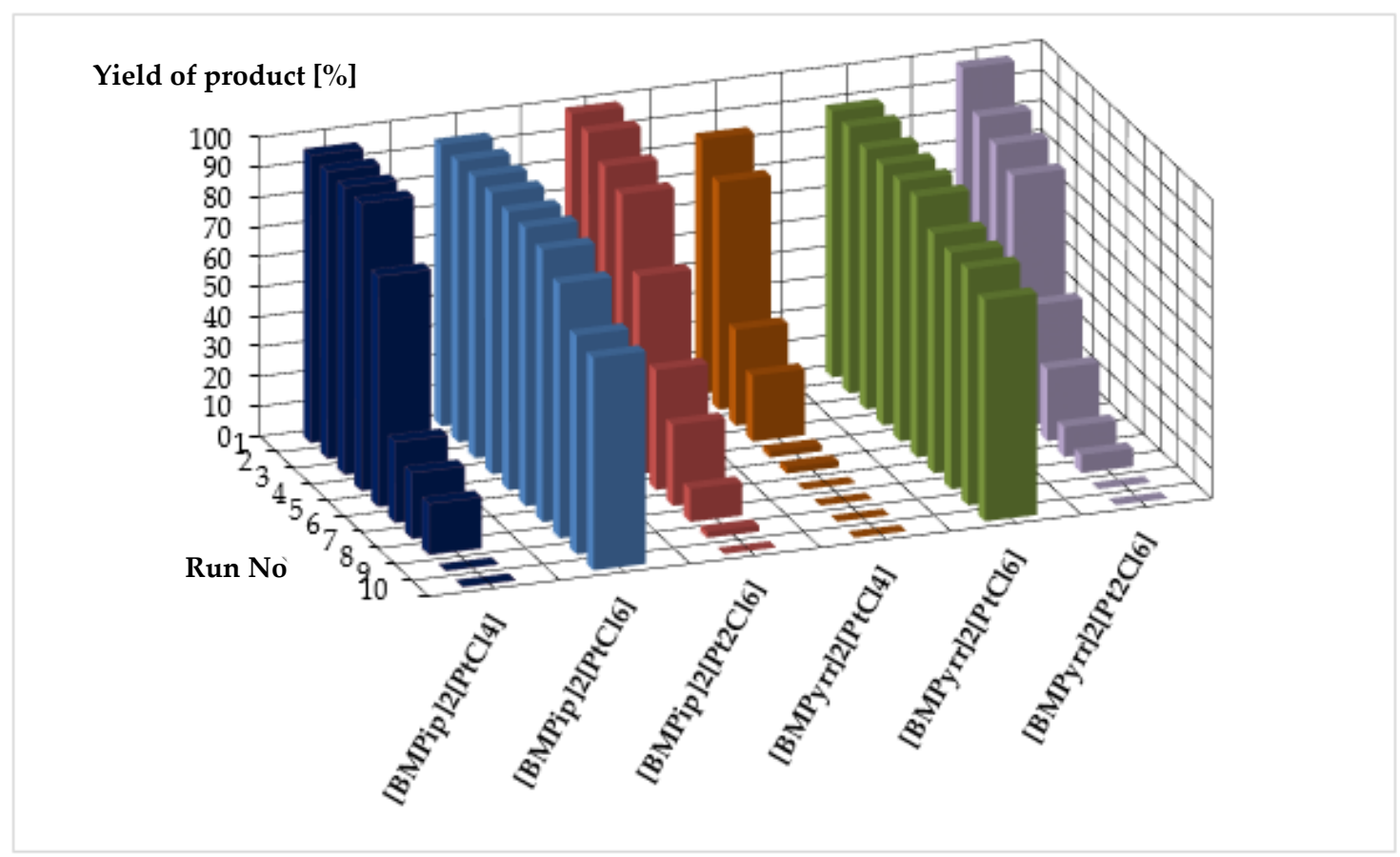

Figure 5. Yields of the product of hydrosilylation of allyl glycidyl ether with 1,1,1,3,5,5,5-heptamethyltrisiloxane as determined for 10 subsequent reaction cycles catalyzed by the same catalyst portion. 
Table 5. Product yields and TON values for hydrosilylation of allyl glycidyl ether with HMTS, catalyzed by anionic platinum complexes.

\begin{tabular}{ccc}
\hline Catalyst & Yield of Product in Subsequent Cycle [\%] & Total TON \\
\hline$[\mathrm{BMPip}]_{2}\left[\mathrm{PtCl}_{4}\right]$ & $94(94,94,94,69,28,27,18,10,5)$ & 53,300 \\
{$[\mathrm{BMPip}]_{2}\left[\mathrm{PtCl}_{6}\right]$} & $99(98,98,98,98,98,98,95,91,90)$ & 96,300 \\
{$[\mathrm{BMPip}]_{2}\left[\mathrm{Pt}_{2} \mathrm{Cl}_{6}\right]$} & $94(94,94,94,94,94,93,93,93,72)$ & 91,500 \\
{$[\mathrm{BMPyrr}]_{2}\left[\mathrm{PtCl}_{4}\right]$} & $93(91,91,83,34,31,26,16,15,15)$ & 49,500 \\
{$[\mathrm{BMPyrr}]_{2}\left[\mathrm{PtCl}_{6}\right]$} & $95(92,92,92,92,91,91,90,90,89)$ & 91,400 \\
{$[\mathrm{BMPyrr}]_{2}\left[\mathrm{Pt}_{2} \mathrm{Cl}_{6}\right]$} & $93(93,93,93,93,93,93,93,84,84)$ & 91,200 \\
\hline
\end{tabular}

$[\mathrm{HSi} \equiv]:[\mathrm{CH}=\mathrm{CH}]:[\mathrm{cat}]=1: 1 \cdot 2: 10^{-4} ; \mathrm{T}=110^{\circ} \mathrm{C} ; \mathrm{t}=1 \mathrm{~h}$.

Additionally, the effect of the cation is more visible because the activity of complexes with piperidinium cation are higher than those with pyrrolidinium cation. This is confirmed by TON values shown in Table 5.

The poorest catalyst turned out to be, also in this case, the complex [BMPyrr $]_{2}\left[\mathrm{PtCl}_{4}\right]$ whose activity began to decline already in the second cycle thus making it impossible to carry out 10 reaction cycles.

The decline in the activity of tetrachloroplatinic complexes in subsequent cycles of both reactions studied can be explained by gradual leaching of these complexes with new portions of reagents. To confirm this explanation we performed the ICP analysis of postreaction mixtures (obtained after the reaction with 1-octene) for the most stable complex $\left[\mathrm{BMPip}_{2}\left[\mathrm{PtCl}_{6}\right]\right.$ and the least stable one $[\mathrm{BMPyrr}]_{2}\left[\mathrm{PtCl}_{4}\right]$. It has been found that in the case of the former complex, $0.22 \%$ of the initial platinum content was leached after the first cycle, whereas after further cycles the amount of leached platinum was below the detection limit. In the case of the latter complex, $2.7 \%$ of the initial platinum content was leached after the first cycle and in subsequent cycles the amounts of leached platinum were comparable. The complexes with hexachloroplatinic anions have stronger ionic character than those with tetrachloroplatinic anion, hence they are less susceptible to leaching with reagents. This is more visible in the case of the reaction with allyl glycidyl ether which is a polar compound, hence the decline in the catalytic activity is faster due to a reduction in catalyst concentration caused by stronger leaching. Taking into consideration the effect of the kind of cation, it is worth mentioning that both cations are heterocyclic derivatives with a six-membered ring in the case of piperidine and five-membered ring in that of pyrrolidine. The structure of the six-membered ring additionally stabilizes the complex and due to this, the performance of the complex with pyrrolidinium cation is more reproducible in the reaction with allyl glycidyl ether. In our earlier studies, we determined the activity of chloroplatinic complexes with cations being derivatives of imidazole and pyridine [37]. Considering analogous complexes with piperidinium $[\mathrm{BMPip}]_{2}\left[\mathrm{PtCl}_{6}\right]$ and pyridinium $[\mathrm{BMPy}]_{2}\left[\mathrm{PtCl}_{6}\right]$ cations and comparing TON values for the reaction with octene 96,300 and 95,200 , respectively [37] and that with allyl glycidyl ether 88,200 and 60,300, respectively [37], one can additionally confirm that saturated six-membered ring better stabilizes the complex than its aromatic counterpart.

\section{Materials and Methods}

\subsection{Materials}

All reagents applied in catalytic measurements, i.e., 1-octene, allyl glycidyl ether, n-decane, and 1,1,1,3,5,5,5-heptamethyltrisiloxane were purchased from Sigma Aldrich (Poznań, Poland) and used as received. Additionally, metal precursors: $\left[\mathrm{Pt}(\operatorname{cod}) \mathrm{Cl}_{2}\right], \mathrm{K}_{2}\left[\mathrm{PtCl}_{6}\right]$ was supplied by Sigma Aldrich (Poznań, Poland). The ionic liquids: 1-Butyl-1-methylpyrrolidinium chloride [BMPyrr]Cl,1-Butyl-1-methylpiperidinium chloride [BMPip] $\mathrm{Cl}$, were purchased from Iolitec $\mathrm{GmbH}$ (Heilbronn, Germany). 


\subsection{Analytical Techniques}

${ }^{1} \mathrm{H}$ NMR and ${ }^{13} \mathrm{C}$ NMR spectra were recorded in acetonitrile-d 3 and chloroform-d, as a solvent, on a Varian 400 operating at 402.6 and $101.2 \mathrm{MHz}$, respectively. GC analyses were carried out on a Clarus 680 gas chromatograph (Perkin Elmer, Shelton, CT, USA) equipped with a $30 \mathrm{~m}$ capillary column Agilent VF-5ms (Santa Clara, CA, USA) and TCD detector, using the temperature program: $60{ }^{\circ} \mathrm{C}(3 \mathrm{~min}), 10^{\circ} \mathrm{C} \mathrm{min}-1,290{ }^{\circ} \mathrm{C}(5 \mathrm{~min})$. ESI-MS spectra were recorded using a QTOF-type mass spectrometer (Impact HD, Bruker, Ettlingen, Germany). Fourier transform infrared FTIR spectra were recorded on a Bruker Tensor 27 Fourier (Billerica, MA, USA) transform spectrophotometer equipped with a SPECAC Golden Gate, diamond ATR unit with a resolution of $2 \mathrm{~cm}^{-1}$. Thermogravimetric analysis (TGA) was carried out using a TA Instruments TG Q50 analyzer (New Castle, DE, USA) at a linear heating rate of $10^{\circ} \mathrm{C} / \mathrm{min}$ under synthetic air $(50 \mathrm{~mL} / \mathrm{min})$. The tested samples were placed in a platinum pan and the weight of the samples was kept within 9-10 $\mathrm{mg}$. The experimental error was $0.5 \%$ for weight and $1{ }^{\circ} \mathrm{C}$ for temperature. Melting points were measured on the Melting Point M-565 instrument (Buchi, Essen, Germany) equipped with a video camera. Temperature gradient: $10{ }^{\circ} \mathrm{C} / \mathrm{min}$. FTIR in situ measurements were performed using a Mettler Toledo ReactIR 15 instrument (Giessen, Germany). For selected samples, spectra were recorded with 256 scans for $1 \mathrm{~h}$ at $30 \mathrm{~s}$ intervals with the resolution of $1 \mathrm{~cm}^{-1}$. Intensity change of the band at $913 \mathrm{~cm}^{-1}$, characteristic of $\equiv \mathrm{Si}-\mathrm{H}$ bond, was recorded using an ATR probe with a diamond window. The ICP-MS analysis of postreaction samples was carried out on a Perkin Elmer Nexion 300D (Waltham, MA, USA) inductively coupled mass spectrometer.

\subsection{Synthesis of Transition-Metal-Based Complexes}

\section{Synthesis of Bis(1-butyl-1-methylpiperidinium) tetrachloroplatinate(II), [BMPip $]_{2}\left[\mathrm{PtCl}_{4}\right]$}

A $25 \mathrm{~mL}$ high-pressure Schlenk vessel equipped with a magnetic stirring bar was charged $0.50 \mathrm{~g}$ (2.6 mmol) of [BMPip]Cl and $0.50 \mathrm{~g}(1.3 \mathrm{mmol})$ of $\left[\mathrm{Pt}(\operatorname{cod}) \mathrm{Cl}_{2}\right]$ in hot $\mathrm{CH}_{3} \mathrm{CN}(2 \mathrm{~mL})$. The reaction mixture was stirred for $24 \mathrm{~h}$ under reflux. After this time, the solution was cooled to room temperature and the solvent was evaporated. The white product was washed with diethyl ether $(3 \times 5 \mathrm{~mL})$ and dried under vacuum. Product yield: $93 \%$ anal. calcd.

${ }^{1} \mathrm{H}$ NMR $\left(\mathrm{ACN}-d_{6}\right) \delta(\mathrm{ppm}): 3.21-3.16\left(\mathrm{~m}, 12 \mathrm{H}, J=7.24 \mathrm{~Hz}, \mathrm{~N}-\mathrm{CH}_{2}\right), 2.88\left(\mathrm{~s}, J=7.14,6 \mathrm{H}, \mathrm{N}-\mathrm{CH}_{3}\right)$, $1.90-1.85\left(\mathrm{~m}, 12 \mathrm{H}, J=7.04,-\mathrm{CH}_{2}-\right), 1.60-1.56\left(\mathrm{~m}, 4 \mathrm{H}, J=7.08,-\mathrm{CH}_{2}-\right), 1.32-1.26(\mathrm{~m}, 4 \mathrm{H}, J=7.01$, $\left.-\mathrm{CH}_{2}-\right), 0.91-0.88\left(\mathrm{t}, 6 \mathrm{H}, \mathrm{J}=7.13,-\mathrm{CH}_{3}\right)$

${ }^{13} \mathrm{C}$ NMR $\left(\mathrm{ACN}-d_{6}\right) \delta(\mathrm{ppm}): 64.79\left(\mathrm{~N}-\mathrm{CH}_{2}\right), 64.49\left(\mathrm{~N}-\mathrm{CH}_{2}\right), 48.88\left(\mathrm{~N}-\mathrm{CH}_{3}\right), 31.01\left(-\mathrm{CH}_{2}-\right), 25.97$, $22.12,19.72\left(-\mathrm{CH}_{2}-\right), 13.12\left(-\mathrm{CH}_{3}\right)$

ESI-MS(+): 156.17 [BMPip] $^{+}$

ESI-MS(-): $265.15\left[\mathrm{PtCl}_{2}\right]^{2-}, 300.86\left[\mathrm{PtCl}_{3}\right]^{-} /\left[\mathrm{Pt}_{2} \mathrm{Cl}_{6}\right]^{2-}, 335.84\left[\mathrm{PtCl}_{4}\right]^{2-}$

\section{Synthesis of Bis(1-butyl-1-methylpyrrolidinium) tetrachloroplatinate(II), [BMPyrr $]_{2}\left[\mathrm{PtCl}_{4}\right]$}

A $25 \mathrm{~mL}$ high-pressure Schlenk vessel equipped with a magnetic stirring bar was charged $0.47 \mathrm{~g}$ (2.6 mmol) of [BMPyrr] Cl and $0.50 \mathrm{~g}(1.3 \mathrm{mmol})$ of $\left[\mathrm{Pt}(\mathrm{cod}) \mathrm{Cl}_{2}\right]$ in hot $\mathrm{CH}_{3} \mathrm{CN}(2 \mathrm{~mL})$. The reaction mixture was stirred for $24 \mathrm{~h}$ under reflux. After this time, the solution was cooled to room temperature and the solvent was evaporated. The white product was washed with diethyl ether $(3 \times 5 \mathrm{~mL})$ and dried under vacuum. Product yield: $92 \%$ anal. calcd.

${ }^{1} \mathrm{H}$ NMR (ACN- $\left.d_{6}\right) \delta(\mathrm{ppm}): 3.49-3.44\left(\mathrm{~m}, 8 \mathrm{H} J=7.3,-\mathrm{N}-\mathrm{CH}_{2}\right), 3.31-3.27\left(\mathrm{~m}, 4 \mathrm{H}, J=7.4,-\mathrm{N}-\mathrm{CH}_{2}\right)$, $2.99\left(\mathrm{~s}, 6 \mathrm{H}, J=7.25,-\mathrm{N}-\mathrm{CH}_{3}\right), 1.99-1.96\left(\mathrm{~m}, 8 \mathrm{H}, J=7.21,-\mathrm{CH}_{2}-\right), 1.76-1.73\left(\mathrm{~m}, 4 \mathrm{H}, J=7.18,-\mathrm{CH}_{2}-\right)$, $1.42-1.38\left(\mathrm{~m}, 4 \mathrm{H}, J=7.15,-\mathrm{CH}_{2}-\right), 1.01-0.98\left(\mathrm{t}, 6 \mathrm{H}, J=7.13,-\mathrm{CH}_{3}\right)$

${ }^{13} \mathrm{C} \mathrm{NMR}\left(\mathrm{ACN}-d_{6}\right) \delta(\mathrm{ppm}): 64.79\left(\mathrm{~N}-\mathrm{CH}_{2}-\right) ; 48.63\left(-\mathrm{N}-\mathrm{CH}_{3}\right) ; 31.09,25.95,21.87,20.05\left(-\mathrm{CH}_{2}-\right) 13.50$ $\left(-\mathrm{CH}_{3}\right)$

ESI-MS(+): 142.13 [BMPyrr] ${ }^{+}$

ESI-MS(-): $265.15\left[\mathrm{PtCl}_{2}\right]^{2-}, 300.98\left[\mathrm{PtCl}_{3}\right]^{-} /\left[\mathrm{Pt}_{2} \mathrm{Cl}_{6}\right]^{2-}, 335.86\left[\mathrm{PtCl}_{4}\right]^{2-}$ 
Synthesis of Bis(1-butyl-1-methylpiperidinium) hexachloroplatinate(IV), [BMPip $]_{2}\left[\mathrm{PtCl}_{6}\right]$

A $25 \mathrm{~mL}$ high-pressure Schlenk vessel equipped with a magnetic stirring bar was charged $0.37 \mathrm{~g}$ ( $2 \mathrm{mmol})$ of [BMPip]Cl and $0.53 \mathrm{~g}(1 \mathrm{mmol})$ of $\mathrm{K}_{2}\left[\mathrm{PtCl}_{6}\right]$ in hot $\mathrm{CH}_{3} \mathrm{CN}(2 \mathrm{~mL})$ were added. The mixture was stirred for $3 \mathrm{~h}$ under reflux followed by filtration by a cannula system. The solvent was evaporated and dried under vacuum to yield orange product. Product yield: $91 \%$ anal. calcd.

${ }^{1} \mathrm{H}$ NMR $\left(\mathrm{ACN}-d_{6}\right) \delta(\mathrm{ppm}): 3.39-3.29\left(\mathrm{~m}, 12 \mathrm{H}, J=7.25 \mathrm{~Hz},-\mathrm{N}-\mathrm{CH}_{2}\right), 3.02\left(\mathrm{~s}, J=7.11,6 \mathrm{H},-\mathrm{N}-\mathrm{CH}_{3}\right)$, $2.06-2.035\left(\mathrm{~m}, 12 \mathrm{H}, J=7.01,-\mathrm{CH}_{2}-\right), 1.77-1.73\left(\mathrm{~m}, 4 \mathrm{H}, J=7.06,-\mathrm{CH}_{2}-\right), 1.49-1.43(\mathrm{~m}, 4 \mathrm{H}, J=7.04$, $\left.-\mathrm{CH}_{2}-\right), 1.08-1.05\left(\mathrm{t}, 6 \mathrm{H}, J=7.10,-\mathrm{CH}_{3}\right)$

${ }^{13} \mathrm{C}$ NMR $\left(\mathrm{ACN}-d_{6}\right) \delta(\mathrm{ppm}): 61.63\left(\mathrm{~N}-\mathrm{CH}_{2}\right), 48.18\left(\mathrm{~N}-\mathrm{CH}_{3}\right), 30.03\left(-\mathrm{CH}_{2}-\right), 23.93,21.19,20.14,20.00$ $\left(-\mathrm{CH}_{2}-\right), 13.26\left(-\mathrm{CH}_{3}\right)$

\section{Synthesis of Bis(1-butyl-1-methylpyrrolidinium) hexachloroplatinate(IV), [BMPyrr $]_{2}\left[\mathrm{PtCl}_{6}\right]$}

A $25 \mathrm{~mL}$ high-pressure Schlenk vessel equipped with a magnetic stirring bar $0.39 \mathrm{~g}$ ( $2 \mathrm{mmol})$ of [BMPyrr] $\mathrm{Cl}$ and $0.56 \mathrm{~g}(1.1 \mathrm{mmol})$ of $\mathrm{K}_{2}\left[\mathrm{PtCl}_{6}\right]$ in hot $\mathrm{CH}_{3} \mathrm{CN}(2 \mathrm{~mL})$ were added. The mixture was stirred for $3 \mathrm{~h}$ under reflux followed by filtration by a cannula system. The solvent was evaporated and dried under vacuum to yield orange product. Product yield: $89 \%$ anal. calcd.

${ }^{1} \mathrm{H}$ NMR $\left(\mathrm{ACN}-d_{6}\right) \delta(\mathrm{ppm}): 3.44-3.43\left(\mathrm{~m}, 8 \mathrm{H} \mathrm{J}=7.11,-\mathrm{N}-\mathrm{CH}_{2}\right), 3.28-3.24\left(\mathrm{~m}, 4 \mathrm{H}, J=7.38,-\mathrm{N}-\mathrm{CH}_{2}\right)$, $2.97\left(\mathrm{~s}, 6 \mathrm{H}, J=7.21,-\mathrm{N}-\mathrm{CH}_{3}\right), 1.80-1.70\left(\mathrm{~m}, 8 \mathrm{H}, J=7.19,-\mathrm{CH}_{2}-\right), 1.44-1.30\left(\mathrm{~m}, 4 \mathrm{H}, J=7.17,-\mathrm{CH}_{2}-\right)$, $1.17-1.13\left(\mathrm{~m}, 4 \mathrm{H}, J=7.12,-\mathrm{CH}_{2}-\right), 1.01-0.97\left(\mathrm{t}, 6 \mathrm{H}, J=7.09,-\mathrm{CH}_{3}\right)$

${ }^{13} \mathrm{C}$ NMR $\left(\mathrm{ACN}-d_{6}\right) \delta(\mathrm{ppm}): 64.79,64.53\left(\mathrm{~N}-\mathrm{CH}_{2}-\right) ; 48.95\left(-\mathrm{N}-\mathrm{CH}_{3}\right) ; 31.26,25.87,22.07,19.78\left(-\mathrm{CH}_{2}-\right)$ $13.54\left(-\mathrm{CH}_{3}\right)$

\section{Synthesis of Bis(1-butyl-1-methylpiperidinium) hexachlorodiplatinate(II), [BMPip $]_{2}\left[\mathrm{Pt}_{2} \mathrm{Cl}_{6}\right]$}

A $25 \mathrm{~mL}$ high-pressure Schlenk vessel equipped with a magnetic stirring bar was added $0.25 \mathrm{~g}$ $(1.3 \mathrm{mmol})$ of [BMPip]Cl and $0.50 \mathrm{~g}(1.3 \mathrm{mmol})$ of $\left[\mathrm{Pt}(\mathrm{cod}) \mathrm{Cl}_{2}\right]$ in hot $\mathrm{CH}_{3} \mathrm{CN}(2 \mathrm{~mL})$. The mixture was stirred for $24 \mathrm{~h}$ under reflux. After this time, the solution was cooled to room temperature and the solvent was evaporated. The white product was washed with diethyl ether $(3 \times 5 \mathrm{~mL})$ and dried under vacuum. Product yield: $93 \%$ anal. calcd.

${ }^{1} \mathrm{H}$ NMR $\left(\mathrm{CDCl}_{3}\right) \delta$ (ppm): $3.87-3.81\left(\mathrm{~m}, 4 \mathrm{H}, J=7.21 \mathrm{~Hz},-\mathrm{N}-\mathrm{CH}_{2}\right), 3.66-3.60(\mathrm{~m}, 8 \mathrm{H}, J=7.23 \mathrm{~Hz}$, $\left.-\mathrm{N}-\mathrm{CH}_{2}\right), 3.37\left(\mathrm{~s}, J=7.14,6 \mathrm{H},-\mathrm{N}-\mathrm{CH}_{3}\right), 1.91-1.82\left(\mathrm{~m}, 12 \mathrm{H}, J=7.03,-\mathrm{CH}_{2}-\right), 1.84-1.66(\mathrm{~m}, 4 \mathrm{H}, J=7.06$, $\left.-\mathrm{CH}_{2}-\right), 1.51-1.41\left(\mathrm{~m}, 4 \mathrm{H}, J=7.01,-\mathrm{CH}_{2}-\right), 1.03-0.99\left(\mathrm{t}, 6 \mathrm{H}, J=7.11,-\mathrm{CH}_{3}\right)$

${ }^{13} \mathrm{C} \mathrm{NMR}\left(\mathrm{CDCl}_{3}\right) \delta(\mathrm{ppm}): 60.58\left(\mathrm{~N}-\mathrm{CH}_{2}\right), 48.39\left(\mathrm{~N}-\mathrm{CH}_{3}\right), 30.67\left(-\mathrm{CH}_{2}-\right), 23.73,20.52,19.99,19.56$ $\left(-\mathrm{CH}_{2}-\right), 13.46\left(-\mathrm{CH}_{3}\right)$

ESI-MS(+): 156.17 [BMPip] $^{+}$

ESI-MS(-): $265.15\left[\mathrm{PtCl}_{2}\right]^{2-}, 300.98\left[\mathrm{PtCl}_{3}\right]^{-} /\left[\mathrm{Pt}_{2} \mathrm{Cl}_{6}\right]^{2-}, 603.47\left[\mathrm{Pt}_{2} \mathrm{Cl}_{6}\right]^{2}$

Synthesis of Bis(1-butyl-1-methylpyrrolidinium) hexachlorodiplatinate(II), [BMPyrr $]_{2}\left[\mathrm{Pt}_{2} \mathrm{Cl}_{6}\right]$

A $25 \mathrm{~mL}$ high-pressure Schlenk vessel equipped with a magnetic stirring bar was added $0.24 \mathrm{~g}$ $(1.3 \mathrm{mmol})$ of [BMPyrr] Cl and $0.50 \mathrm{~g}(1.3 \mathrm{mmol})$ of $\left[\mathrm{Pt}(\mathrm{cod}) \mathrm{Cl}_{2}\right]$ in hot $\mathrm{CH}_{3} \mathrm{CN}(2 \mathrm{~mL})$. The mixture was stirred for $24 \mathrm{~h}$ under reflux. After this time, the solution was cooled to room temperature and the solvent was evaporated. The white product was washed with diethyl ether $(3 \times 5 \mathrm{~mL})$ and dried under vacuum. Product yield: $90 \%$ anal. calcd.

${ }^{1} \mathrm{H}$ NMR $\left(\mathrm{CDCl}_{3}\right) \delta(\mathrm{ppm}): 3.89-3.75\left(\mathrm{~m}, 8 \mathrm{H}, J=7.42,-\mathrm{N}-\mathrm{CH}_{2}\right), 3.63-3.59\left(\mathrm{~m}, 4 \mathrm{H}, J=7.24,-\mathrm{N}-\mathrm{CH}_{2}\right)$, $3.30\left(\mathrm{~s}, 6 \mathrm{H}, J=7.20,-\mathrm{N}-\mathrm{CH}_{3}\right), 1.81-1.53\left(\mathrm{~m}, 12 \mathrm{H}, J=7.18,-\mathrm{CH}_{2}-\right), 1.51-1.44\left(\mathrm{~m}, 4 \mathrm{H}, J=7.16,-\mathrm{CH}_{2}-\right)$, $1.05-1.01\left(\mathrm{t}, 6 \mathrm{H}, \mathrm{J}=7.09,-\mathrm{CH}_{3}\right)$

${ }^{13} \mathrm{C}$ NMR $\left(\mathrm{CDCl}_{3}\right) \delta(\mathrm{ppm}): 64.51\left(\mathrm{~N}-\mathrm{CH}_{2}-\right), 64.05\left(-\mathrm{N}-\mathrm{CH}_{3}\right), 30.09,26.09,21.63,19.74\left(-\mathrm{CH}_{2}-\right) 13.74$ $\left(-\mathrm{CH}_{3}\right)$

ESI-MS(+): 142.13 [BMPyrr] ${ }^{+}$

ESI-MS(-): $265.15\left[\mathrm{PtCl}_{2}\right]^{2-}, 300.98\left[\mathrm{PtCl}_{3}\right]^{-} /\left[\mathrm{Pt}_{2} \mathrm{Cl}_{6}\right]^{2-}, 602.89\left[\mathrm{Pt}_{2} \mathrm{Cl}_{6}\right]^{2-}$

NMR and ESI-MS spectra of these complexes are presented in Supplementary Materials. 


\subsection{General Procedure for Catalytic Tests}

To investigate the catalytic activity of platinum anionic complexes the hydrosilylation reactions of 1-octene or allyl glycidyl ether with 1,1,1,3,5,5,5-heptamethyltrisiloxane (HMTS) were carried out. The $5 \mathrm{~mL}$ glass reactor equipped with a reflux condenser was charged with $3.68 \mathrm{mmol}$ of 1-octene or $4.41 \mathrm{mmol}$ of allyl glycidyl ether and $3.68 \mathrm{mmol}$ of HMTS. Then, $10^{-4} \mathrm{~mol}$ of Pt per $1 \mathrm{~mol}$ of Si-H was applied. As an internal standard $1 \mathrm{mmol}$ of $\mathrm{n}$-decane was added. The reaction was carried out in the presence of air at $110{ }^{\circ} \mathrm{C}$ for $1 \mathrm{~h}$, without stirring. After each catalytic cycle, the reaction mixture was cooled down and subjected to GC analysis to determine the reaction yield. The product was isolated and subjected to NMR analyses. Due to a very small amount of catalyst, the products were entirely taken with a needle-equipped syringe after the reaction completion and a new portion of the reaction substrates was added to the reaction vessel, followed by conducting the reaction in the same way as described above. The catalyst remaining in the flask was not washed or regenerated in any way. The above operation was repeated 10 times.

3-octyl-1,1,1,3,5,5,5-heptamethyltrisiloxane:

${ }^{1} \mathrm{H}$ NMR ( $\left.\mathrm{CDCl}_{3}\right)$ ppm: $1.36-1.27\left(\mathrm{~m} ; 12 \mathrm{H} ; \mathrm{CH}_{2}-\mathrm{CH}_{2}-\mathrm{CH}_{2}\right) ; 0.9\left(\mathrm{t} ; 3 \mathrm{H} ; \mathrm{CH}_{2}-\mathrm{CH}_{3}\right), 0.48\left(\mathrm{t} ; 2 \mathrm{H} ; \mathrm{Si}-\mathrm{CH}_{2}\right)$, $0.11\left(\mathrm{~m}, 18 \mathrm{H}, \mathrm{Si}-\left(\mathrm{CH}_{3}\right)_{3}\right), 0.02\left(\mathrm{~s}, 3 \mathrm{H} \mathrm{Si}-\mathrm{CH}_{3}\right)$.

${ }^{13} \mathrm{C}$ NMR ( $\left.\mathrm{CDCl}_{3}\right)$ ppm: 33.25 (C-C-C); 31.95 (C-C-C), 29.35, $29.27(\mathrm{C}-\mathrm{C}-\mathrm{C}), 23.07\left(\mathrm{C}-\mathrm{CH}_{3}\right), 22.70$ $(\mathrm{Si}-\mathrm{C}-\mathrm{C}), 17.63(\mathrm{C}-\mathrm{Si}), 14.10\left(\mathrm{C}-\mathrm{CH}_{3}\right), 1.89\left(\mathrm{Si}-\mathrm{CH}_{3}\right), 0.28\left(\mathrm{O}-\mathrm{Si}-\mathrm{CH}_{3}\right)$.

${ }^{29} \mathrm{Si}$ NMR $\left(\mathrm{CDCl}_{3}\right)$ ppm: -2.19 (-O-Si-O-), $6.75\left(\mathrm{OSi}_{(}\left(\mathrm{CH}_{3}\right)_{3}\right)$.

\section{3-(3-glycidyloxypropyl)-1,1,1,3,5,5,5-heptamethyltrisiloxane:}

${ }^{1} \mathrm{H}$ NMR $\left(\mathrm{CD}_{3} \mathrm{CN}\right)$ ppm: $3.69\left(\mathrm{~m}, J=17.1 \mathrm{~Hz}, 1 \mathrm{H},-\mathrm{O}-\mathrm{CH}_{2}-\right) ; 3.43\left(\mathrm{~m}, 2 \mathrm{H},-\mathrm{CH}_{2}-\mathrm{O}-\mathrm{CH}_{2}-\right) ; 3.27(\mathrm{dd}$, $\left.J=11.5 \mathrm{~Hz}, 1 \mathrm{H},-\mathrm{O}-\mathrm{CH}_{2}-\right) ; 3.08\left(\mathrm{~m}, J=6.8 \mathrm{~Hz}, 1 \mathrm{H}, \mathrm{HC}-\mathrm{O}-\mathrm{CH}_{2}-\right) ; 2.74\left(\mathrm{dd}, J=5.1 \mathrm{~Hz}, 1 \mathrm{H}, \mathrm{HC}-\mathrm{CH}_{2}-\mathrm{O}\right)$; $2.54\left(\mathrm{~m}, J=5.1 \mathrm{~Hz}, 1 \mathrm{H}, \mathrm{HC}-\mathrm{CH}_{2}-\mathrm{O}\right) ; 0.05\left(\mathrm{~m}, 3 \mathrm{H},-\mathrm{SiCH}_{3}\right) ; 1.59\left(\mathrm{~m}, J=11.3 \mathrm{~Hz}, 2 \mathrm{H},-\mathrm{Si}_{-}-\mathrm{CH}_{2}-\mathrm{CH}_{2}-\right)$; $0.5\left(\mathrm{~m}, 2 \mathrm{H},-\mathrm{Si}-\mathrm{CH}_{2}-\right) ; 0.13\left(\mathrm{~m}, 18 \mathrm{H},-\mathrm{Si}\left(\mathrm{CH}_{3}\right)_{3}\right)$;

${ }^{13} \mathrm{C}$ NMR $\left(\mathrm{CD}_{3} \mathrm{CN}, \delta\right.$, ppm): 73.67 (-C-C-O-); 71.41 (-O-C-C-); 50.71 (-C-O-C-); 43.56 (-C-O-C-); $23.16(-\mathrm{Si}-\mathrm{C}-\mathrm{C}-)$; $12.77(-\mathrm{Si}-\mathrm{C}-)$; $0.37-1.39\left(-\mathrm{Si}\left(\mathrm{CH}_{3}\right)_{3}\right) ;-1.0\left(-\mathrm{Si}-\mathrm{CH}_{3}\right)$.

${ }^{29} \mathrm{Si}$ NMR $\left.\left(\mathrm{CD}_{3} \mathrm{CN}, \delta, \mathrm{ppm}\right):-20.52(-\mathrm{O}-\mathrm{Si}-\mathrm{O}-), 8.07\left(\mathrm{OSi}_{(\mathrm{CH}}\right)_{3}\right)$.

NMR spectra of these products are presented in Supplementary Materials.

\section{Conclusions}

Six new air-stable anionic platinum complexes were synthesized with high yields in the reaction of a suitable ionic liquid and platinum compound and the complexes were fully characterized. Derivatives of piperidine and pyrrolidine, which were precursors of the formed complexes, have been chosen for the syntheses. Due to high melting points (above $100{ }^{\circ} \mathrm{C}$ ), the newly formed complexes cannot be formally classified into ionic liquids, but the ionic structure significantly influences their catalytic activity and stability. All the complexes proved to be highly active in the reactions of hydrosilylation of 1-octene and allyl glycidyl ether with 1,1,1,3,5,5,5-heptamethyltrisiloxane. Their insolubility (or limited solubility) in the reagents enabled easy isolation from postreaction mixtures and multiple uses of them in subsequent reaction cycles. The performed studies have shown that the kind of anion influences to a large extent the catalytic activity and, first and foremost, the stability of the complexes. The most stable complexes turned to be those with $\left[\mathrm{PtCl}_{6}\right]^{2-}$ anion due to their stronger ionic character compared to analogous complexes with $\left[\mathrm{PtCl}_{4}\right]^{2-}$ anion. Moreover, the complexes containing the six-membered heterocyclic ring (piperidinium) are more stable than those containing the five-membered ring (pyrrolidinium). Hexachloroplatinic complexes, particularly the complex $\left[\mathrm{BMPip}_{2}\left[\mathrm{PtCl}_{6}\right]\right.$, make an attractive alternative not only to known homogeneous complexes but also to heterogeneous catalysts applied in hydrosilylation processes. High catalytic activity and stability of the latter complex make possible its multiple uses which is of high importance both from an ecological and economic viewpoint. 
Supplementary Materials: The following are available online at http://www.mdpi.com/2073-4344/10/8/919/s1, Figure S1-Figure S12: NMR Spectra of complexes, Figure S13-Figure S20: ESI-MS spectra of complexes, Figure S21-Figure S26: NMR spectra of isolated products

Author Contributions: Synthesis of platinum complexes, methodology, M.J.-W.; catalytic tests, O.B.; FTIR in situ analyzes, O.B. and P.P.; conceptualization, M.J.-W. and H.M.; writing-original draft preparation, M.J.-W. and H.M.; writing-review and editing, M.J.-W., H.M., and O.W.; supervision, H.M.; funding acquisition, H.M. All authors have read and agreed to the published version of the manuscript.

Funding: This research was supported by grant OPUS UMO-2014/15/B/ST5/04257, funded by National Science Center (Poland)

Conflicts of Interest: The authors declare no conflicts of interest.

\section{References}

1. Anastas, P.T.; Warner, J.C. Green Chemistry: Theory and Practice; Oxford University Press: New York, NY, USA, 1998; p. 30.

2. Marciniec, B.; Maciejewski, H.; Pietraszuk, C.; Pawluć, P. Hydrosilylation: A Comprehensive Review on Recent Advances; Marciniec, B., Ed.; Springer: Dordrecht, The Netherlands, 2009.

3. Trogel, D.; Strohrer, J. Recent advances and actual challenges in late transition metal catalyzed hydrosilylation of olefins from an industrial point of view. Coord. Chem. Rev. 2011, 255, 1440-1459. [CrossRef]

4. Marciniec, B.; Maciejewski, H.; Pawluć, P. Organosilicon Compounds; Lee, V.Y., Ed.; Academic Press: Cambridge, MA, USA, 2017; Chapter 5; pp. 169-218.

5. Marciniec, B.; Maciejewski, H.; Pietraszuk, C.; Pawluć, P. Applied Homogeneous Catalysis with Organometallic Compounds; Cornils, B., Hermann, W.A., Belier, M., Pawelo, R., Eds.; Wiley: New York, NY, USA, 2017; Chapter 8; pp. 569-620.

6. Nakajima, Y.; Shimada, S. Hydrosilylation reaction of olefins: Recent advances and perspectives. RSC Adv. 2015, 5, 20603-20616. [CrossRef]

7. Roger, R.D.; Seddon, K.R. (Eds.) Ionic Liquids-Industrial Applications to Green Chemistry; ACS: Washington, DC, USA, 2002.

8. Dyson, P.J.; Geldbach, T.J. Metal Catalysed Reactions in Ionic Liquids; Springer: Dordrecht, The Netherlands, 2005.

9. Hardacre, C.; Parvulescu, V. Catalysis in Ionic Liquids. From Catalyst Synthesis to Application; RS Chemistry: London, UK, 2014.

10. Vekariya, R.L. A review of ionic liquids: Applications towards catalytic organic transformations. J. Mol. Liq. 2017, 227, 44-60. [CrossRef]

11. Ozokwelu, D.; Zhang, S.; Okafor, O.C.; Cheng, W.; Litombe, N. Novel Catalytic and Separation Processes Based on Ionic Liquids; Elsevier: Amsterdam, The Netherlands, 2017.

12. Lozano, P. (Ed.) Sustainable Catalysis in Ionic Liquids; CRC Press: Boca Raton, FL, USA, 2019.

13. Behr, A.; Toslu, N. Hydrosilylation reactions in single and two phases. Chem. Eng. Technol. 2000, 23, $122-125$. [CrossRef]

14. Hofmann, N.; Bauer, A.; Auer, T.; Stanjek, V.; Schulz, P.; Taccardi, N.; Wasserscheid, P. Liquid-liquid biphasic, platinum-catalyzed hydrosilylation of allyl chloride with trichlorosilane using an ionic liquid catalyst phase in a continuous loop reactor. Adv. Synth. Catal. 2008, 350, 2599-2609. [CrossRef]

15. Taccardi, N.; Fekete, M.; Berger, M.E.; Stanjek, V.; Schulz, P.; Wasserscheid, P. Catalyst recycling in monophasic Pt-catalyzed hydrosilylation reactions using ionic liquids. Appl. Catal. A 2011, 399, 69-74. [CrossRef]

16. Weyershausen, B.; Hell, K.; Hesse, U. Industrial application of ionic liquids as process aid. Green Chem. 2005, 7, 283-287. [CrossRef]

17. Schulz, T.; Strassner, T. Biphasic platinum catalyzed hydrosilylation of terminal alkenes in TAAILs. J. Organometal. Chem. 2013, 744, 113-118. [CrossRef]

18. Maciejewski, H.; Szubert, K.; Marciniec, B.; Pernak, J. Hydrosilylation of functionalised olefins catalysed by rhodium siloxide complexes in ionic liquids. Green Chem. 2009, 11, 1045-1051. [CrossRef]

19. Zielinski, W.; Kukawka, R.; Maciejewski, H.; Smiglak, M. Ionic liquids as solvents for rhodium and platinum catalysts used in hydrosilylation reaction. Molecules 2016, 21, 1115. [CrossRef]

20. Maciejewski, H.; Szubert, K.; Fiedorow, R.; Giszter, R.; Niemczak, M.; Pernak, J. Diallyldimethylammonium and trimethylvinylammonium ionic liquids-Synthesis and application to catalysis. Appl. Catal. A 2013, 451, 168-175. [CrossRef] 
21. Maciejewski, H.; Jankowska-Wajda, M.; Dabek, I.; Fiedorow, R. The effect of the morpholinium ionic liquid anion on the catalytic activity of $\mathrm{Rh}$ (or $\mathrm{Pt}$ ) complex-ionic liquid systems in hydrosilylation processes. RSC Adv. 2018, 8, 26922-26927.

22. Jankowska-Wajda, M.; Kukawaka, R.; Smiglak, M.; Maciejewski, H. The effect of the catalyst and the type of ionic liquid on the hydrosilylation process under batch and continuous reaction conditions. New J. Chem. 2018, 42, 5229-5236. [CrossRef]

23. Luska, K.L.; Demmans, K.Z.; Stratton, S.A.; Moores, A. Rhodium complexes stabilized by phosphine-functionalized phosphonium ionic liquids used as higher alkene hydroformylation catalysts: Influence of the phosphonium headgroup on catalytic activity. Dalton Trans. 2012, 41, 13533-13540. [CrossRef]

24. Jin, X.; Xu, X.-F.; Zhao, K. Amino acid- and imidazolium-tagged chiral pyrrolidinodiphosphine ligands and their applications in catalytic asymmetric hydrogenations in ionic liquid systems. Tetrahedron Asymmetry 2012, 23, 1058-1067. [CrossRef]

25. Chen, S.J.; Wang, Y.Y.; Yao, W.M.; Zhao, X.L.; Vo-Thanh, G.; Liu, Y. An ionic phosphine-ligated rhodium (III) complex as the efficient and recyclable catalyst for biphasic hydroformylation of 1-octene. J. Mol. Catal. A Chem. 2013, 378, 293-298. [CrossRef]

26. Jankowska-Wajda, M.; Bartlewicz, O.; Szpecht, A.; Zając, A.; Smiglak, M.; Maciejewski, H. Platinum and rhodium complexes ligated by imidazolium-substituted phosphine as efficient and recyclable catalysts for hydrosilylation. RSC Adv. 2019, 9, 29396-29404. [CrossRef]

27. Bartlewicz, O.; Jankowska-Wajda, M.; Maciejwski, H. Highly efficient and reusable alkyne hydrosilylation catalysts based on rhodium complexes ligated by imidazolium- substituted phosphine. Catalysts 2020, 10, 608. [CrossRef]

28. Parvulescu, V.I.; Hardacre, C.h. Catalysis in ionic liquids. Chem. Rev. 2007, 107, 2615-2665. [CrossRef]

29. Lee, J.W.; Chan, Y.S.; Jang, H.B.; Song, C.E.; Lee, S.-G. Toward understanding the origin of positive effects of ionic liquids on catalysis: Formation of more reactive catalysts and stabilization of reactive intermediates and transition states in ionic liquids. Acc. Chem. Res. 2010, 43, 985-994. [CrossRef]

30. Wang, S.; Hui, S.; Shengjie, C.h.; Honqxing, Y.H.; Ye, L. Applications of transition metallates in catalysis. Prog. Chem. 2012, 24, 2287-2298.

31. Estager, J.; Holbrey, J.D.; Swadzba-Kwasny, M. Halometallate ionic liquids-revisited. Chem. Soc. Rev. 2014, 43, 985-994. [CrossRef] [PubMed]

32. Chiappe, C.; Ghilardi, T.; Pomelli, C.S. Structural features and properties of metal complexes in ionic liquids: Application in alkylation reactions. Top. Organomet. Chem. 2015, 51, 79-94.

33. Brown, L.C.; Hogg, J.M.; Swadzba-Kwasny, M. Lewis Acidic Ionic Liquids. Top. Curr. Chem. 2017, 5, 78-117. [CrossRef]

34. Wilkes, J.S. A short history of ionic liquids-From molten salts to neoteric solvents. Green Chem. 2002, 4, 73-80. [CrossRef]

35. Hasan, M.; Kozhevnikov, I.V.; Siddiqui, M.R.H.; Femoni, C.; Steiner, A.; Winterton, N. $N, N^{\prime}$-dialkylimidazolium chloroplatinate(II), chloroplatinate(IV), and chloroiridate(IV) salts and an $\mathrm{N}$-heterocyclic carbene complex of platinum(II): Synthesis in ionic liquids and crystal structures. Inorg. Chem. 2001, 40, 795-800. [CrossRef]

36. Zhong, C.; Sasaki, T.; Jimbo-Kobayashi, A.; Fujiwara, E.; Kobayashi, A.; Tada, M.; Iwasawa, Y. Syntheses, structures, and properties of a series of metal ion-containing dialkylimidazolium ionic liquids. Bull. Chem. Soc. Jpn. 2007, 12, 2365-2374. [CrossRef]

37. Jankowska-Wajda, M.; Bartlewicz, O.; Walczak, A.; Stefankiewicz, A.R.; Maciejewski, H. Highly efficient hydrosilylation catalysts based on chloroplatinate ionic liquids. J. Catal. 2019, 374, 266-275. [CrossRef]

38. Maciejewski, H.; Jankowska-Wajda, M.; Bartlewicz, O. New Anionic Platinum Complexes, Method for Obtaining Them and Application, Preferably for Hydrosilylation Processes. Polish Patent PL 233547, 11 March 2019.

(C) 2020 by the authors. Licensee MDPI, Basel, Switzerland. This article is an open access article distributed under the terms and conditions of the Creative Commons Attribution (CC BY) license (http://creativecommons.org/licenses/by/4.0/). 